\title{
Korelasi Kadar Timbal dalam Darah dengan Kadar Hemoglobin pada Anak Usia 1-6 tahun
}

\author{
Hendra Purnasidha Bagaswoto, Sutaryo, Sasmito Nugroho \\ Departemen Ilmu Kesehatan Anak Fakultas Kedokteran Universitas Gadjah Mada/RS Dr. Sardjito, Yogyakarta
}

\begin{abstract}
Latar belakang. Anak yang berusia kurang dari 6 tahun lebih rentan terpapar timbal. Timbal menghambat proses pembentukan hemoglobin dengan cara menghambat aktivitas enzim amino levulinic acid synthetase (ALAS), amino levulinic acid dehydratase (ALAD) dan ferrochelatase serta menghasilkan reactive oxygen substance (ROS) yang dapat menyebabkan hemolisis.

Tujuan. Menentukan korelasi kadar timbal dalam darah dengan kadar hemoglobin pada anak usia 1-6 tahun.

Metode. Penelitian cross-sectional dilaksanakan bulan Oktober-November 2012. Subjek, anak berusia 1-6 tahun yang bertempat tinggal di sekitar perempatan padat lalu lintas di daerah Gedongtengen, Pingit, dan Juminahan Yogyakarta. Kadar timbal dalam darah dianalisis dengan metode atomic absorption spectrophotometry (AAS) dan kadar hemoglobin dengan metode spektrofotometer. Analisis korelasi Spearman digunakan untuk menentukan korelasi antara kadar timbal dalam darah dengan kadar hemoglobin. Hasil. Sebanyak 65 anak diikutsertakan dalam penelitian dengan rerata usia 3 tahun 10 bulan. Kadar timbal dalam darah di dalam kisaran 0,01-10,67 $\mu \mathrm{g} / \mathrm{dL}$, dengan rerata 3,73 $\mu \mathrm{g} / \mathrm{dL}$. Enam anak (9\%) mempunyai kadar timbal dalam darah tinggi menurut kriteria CDC dan AAP. Tidak ditemukan korelasi yang bermakna antara kadar timbal dalam darah dengan kadar hemoglobin $(\mathrm{r}=0,05 ; \mathrm{p}=0,67)$.

Kesimpulan. Kadar timbal dalam darah tidak memiliki korelasi dengan kadar hemoglobin pada anak usia 1-6 tahun. Sari Pediatri 2015;17(4):297-301.
\end{abstract}

Kata kunci: kadar timbal dalam darah, kadar hemoglobin, anak

\section{Correlation between Blood Lead Level and Hemoglobin Levels in 1-6 Years of Age Children}

Hendra Purnasidha Bagaswoto, Sutaryo, Sasmito Nugroho

Background. Children, especially under 6 years old are more susceptible to lead exposure. Lead inhibits the formation of hemoglobin by inhibiting the enzyme activity of amino levulinic acid synthetase (ALAS), amino levulinic acid dehydratase (ALAD), ferrochelatase and generate reactive oxygen substance (ROS) that can cause hemolysis.

Objective. To determine correlation between blood lead levels to hemoglobin levels in 1-6 years of age children.

Methods. A cross-sectional study was done from October 2012 to November 2012. Subjects were children aged 1-6 years who lived around a crowded traffic intersection at Gedongtengen, Pingit, and Juminahan Yogyakarta. Blood lead and hemoglobin levels were measured by atomic absorption spectrophotometry (AAS) and spectrophotometry method respectively. Blood lead and hemoglobin levels correlation were determined by using Spearman correlation test.

Results. Of 65 children enrolled in this study, $25(38 \%)$ were boys and $40(62 \%)$ were girls with mean aged was 3 year and 10 month old. Blood lead levels ranged from 0.01-10.67 $\mu \mathrm{g} / \mathrm{dL}$ with mean value of $3.73 \mu \mathrm{g} / \mathrm{dL}$. Six children $(9 \%)$ had high blood lead levels according to CDC and AAP criteria. There was no significant correlation between blood lead and hemoglobin levels $(\mathrm{r}=0.05 ; \mathrm{p}=0.67)$.

Conclusion. Blood lead levels has no significant correlation with hemoglobin levels in 1-6 years of age children. Sari Pediatri 2015;17(4):297-301.

Keywords: blood lead levels, hemoglobin levels, children

\footnotetext{
Alamat korespondensi: Dr. Hendra Purnasidha Bagaswoto. Departemen Ilmu Kesehatan Anak FK UGM/RS Dr. Sardjito. Jl. Kesehatan No.1 Yogyakarta, 55284, Indonesia. Tel. +62-274-489726, 561616, Fax: +62-274-583745, E-mail: hendra.purnasidha@gmail.com
} 
Paparan timbal dari lingkungan dapat memengaruhi kadar hemoglobin. Kadar timbal dalam darah yang tinggi dapat menurunkan konsentrasi hemoglobin dengan cara menghambat aktivitas enzim amino levulinic acid synthetase (ALAS), amino levulinic acid dehydratase (ALAD), dan ferrochelatase serta menghasilkan reactive oxygen substance (ROS) yang dapat menyebabkan hemolisis. ${ }^{1-3}$ Manusia dapat terpapar timbal melalui makanan, air, ataupun udara. ${ }^{1}$ Di kota Yogyakarta, paparan timbal meningkat dari tahun ke tahun, terutama dari asap kendaraan bermotor seiring pertambahan jumlah kendaraan. ${ }^{4-6}$ Anak-anak, terutama yang berusia kurang dari 6 tahun, lebih rentan terpapar timbal daripada orang dewasa karena aktivitas hand to mouth mereka, laju pernapasan, serta absorpsi melalui saluran pencernaan yang lebih tinggi. ${ }^{1,2,7-12,13}$

Hubungan antara kadar timbal dalam darah dengan kadar hemoglobin dari hasil beberapa penelitian masih kontroversial. Sebagian melaporkan timbal berhubungan dengan penurunan kadar hemoglobin, ,14-16,17 sebagian lain melaporkan timbal tidak berhubungan dengan kadar hemoglobin. ${ }^{18-20}$ Penelitian ini bertujuan untuk menentukan korelasi kadar timbal dalam darah dengan kadar hemoglobin pada anak.

\section{Metode}

Penelitian cross-sectional dilakukan di kawasan sekitar perempatan yang padat lalu lintas di daerah Gedongtengen, Pingit, dan Juminahan Yogyakarta pada bulan Oktober-November 2012. Subjek diambil secara consecutive sampling saat acara Posyandu. Kriteria inklusi adalah anak berusia 1-6 tahun, dan orang tua setuju anaknya diikutkan dalam penelitian dengan menandatangani informed consent. Kriteria eksklusi adalah demam atau dalam pengobatan penyakit kronis. Dengan mengambil perkiraan koefisien korelasi $0,4,{ }^{17}$ kesalahan tipe I $5 \%$, dan tipe II 20\% maka besar sampel minimal yang diperlukan berdasarkan perhitungan besar sampel untuk uji korelasi adalah 37 anak.

Pengukuran kadar timbal dan hemoglobin dilakukan dengan cara pengambilan sampel darah vena anak $\pm 3 \mathrm{ml}$. Kadar timbal dalam darah diperiksa dengan metode atomic absorption spectrophotometry (AAS), sedangkan hemoglobin dengan metode spektrofotometri. Pemeriksaan dilakukan di Labora- torium Kesehatan Daerah (LABKESDA) DIY. Data karakteristik subjek penelitian, meliputi berat badan dan tinggi badan (untuk pengukuran status gizi), status perokok pasif (anak yang menghirup asap rokok dari anggota keluarga yang merokok) serta sumber air dalam kehidupan rumah tangga sehari-hari juga diambil. Status gizi dikategorikan berdasarkan kriteria WHO growth chart (anak usia 0-60 bulan) dan CDC (anak usia >60 bulan). Penelitian ini telah disetujui oleh Komite Etik dari Fakultas Kedokteran Universitas Gadjah Mada/RSUP Dr. Sardjito Yogyakarta.

Data dianalisis secara statistik dengan menggunakan paket SPSS versi 20 (IBM corporation, New York). Karakteristik subjek penelitian dipresentasikan sebagai frekuensi dan simpang baku. Korelasi antara kadar timbal dalam darah dengan kadar hemoglobin dianalisis dengan uji korelasi Spearman dengan tingkat kemaknaan $\mathrm{p}<0,05$.

\section{Hasil}

Terdapat 74 anak yang memenuhi kriteria inklusi, 9 anak tidak diikutsertakan dalam penelitian dan analisis karena menangis saat dilakukan pengambilan darah sehingga jumlah subjek penelitian akhir adalah 65 anak. Subjek penelitian berusia antara 13-72 bulan dengan rerata usia 46 bulan ( 3 tahun 10 bulan). Rerata kadar timbal dalam darah pada penelitian ini adalah

Tabel 1. Karakteristik subjek $(\mathrm{n}=65)$

\begin{tabular}{ll}
\hline Umur (bulan), rerata (SB) & $46(18)$ \\
Jenis kelamin, n (\%) & \\
$\quad$ Laki-laki & $25(38)$ \\
$\quad$ Perempuan & $40(62)$ \\
Status gizi, n (\%) & \\
$\quad$ Baik & $61(94)$ \\
Kurang & $1(1)$ \\
$\quad$ Lebih & $0(0)$ \\
$\quad$ Obesitas & $3(5)$ \\
Status perokok pasif, n (\%) & \\
$\quad$ Perokok pasif & $47(72)$ \\
$\quad$ Bukan perokok pasif & $18(28)$ \\
Sumber air, n (\%) & \\
$\quad$ Sumur & $33(51)$ \\
$\quad$ PAM & $32(49)$ \\
\hline
\end{tabular}


$3,73 \mu \mathrm{g} / \mathrm{dL}$, dengan kadar timbal dalam darah terendah $0,01 \mu \mathrm{g} / \mathrm{dL}$ dan tertinggi $10,67 \mu \mathrm{g} / \mathrm{dL}$. Enam anak mempunyai kadar timbal dalam darah yang tinggi menurut kriteria CDC dan AAP $(\geq 10 \mu \mathrm{g} / \mathrm{dL})$. Dari keenam anak tersebut, lima di antaranya merupakan perokok pasif dan menggunakan sumber air dari ledeng (PAM) untuk kehidupan sehari-hari.

Kadar timbal dalam darah tidak mempunyai korelasi dengan kadar hemoglobin $(\mathrm{r}=0,05 ; \mathrm{p}=0,67)$. Peningkatan kadar timbal dalam darah tidak diikuti dengan penurunan kadar hemoglobin.

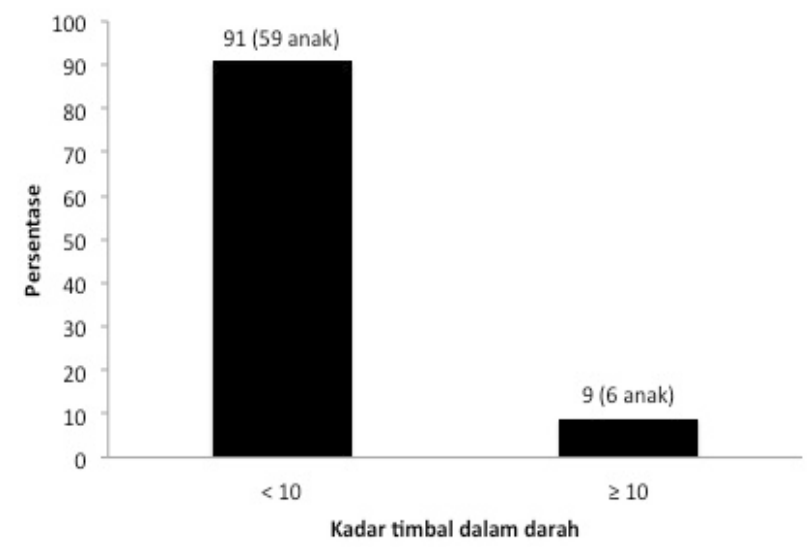

Gambar 1. Distribusi frekuensi kadar timbal dalam darah

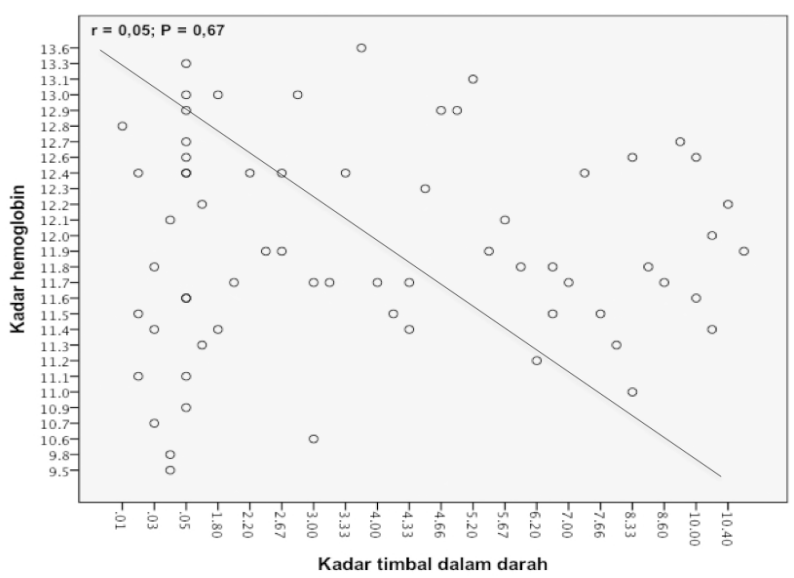

Gambar 2. Scattered plots kadar timbal dalam darah dengan kadar hemoglobin

\section{Pembahasan}

Kami mendapatkan rata-rata kadar timbal dalam darah pada anak usia 1-6 tahun adalah 3,73 $\mu \mathrm{g} / \mathrm{dL}$ dan enam (9\%) anak di antaranya memiliki kadar timbal dalam darah $\geq 10 \mu \mathrm{g} / \mathrm{dL}$. Hasil tersebut berbeda dengan beberapa penelitian lain yang melaporkan bahwa $>50 \%$ anak dalam penelitiannya memiliki kadar timbal dalam darah $\geq 10 \mu \mathrm{g} / \mathrm{dL} .{ }^{1,15-17,21,22}$ Centre for disease and prevention control (CDC) dan American Academy of Pediatrics (AAP) merekomendasikan batas aman kadar timbal dalam darah anak yaitu $<10 \mu \mathrm{g} /$ dL. Anak dengan kadar timbal dalam darah $\geq 10 \mu \mathrm{g} /$ dL dianjurkan untuk dilakukan evaluasi ulang 3 bulan kemudian disertai edukasi untuk pencegahan paparan timbal yang lebih jauh. ${ }^{23,24}$

Kami tidak menemukan korelasi yang bermakna antara kadar timbal dalam darah dengan kadar hemoglobin. Hasil tersebut berbeda dengan laporan penelitian sebelumnya yang menemukan kadar timbal dalam darah memiliki korelasi negatif dengan kadar hemoglobin. ${ }^{1,15-17}$ Perbedaan tersebut mungkin disebabkan rendahnya rata-rata kadar timbal dalam darah anak pada penelitian kami. Belum ada ambang batas tertentu kadar timbal dalam darah untuk timbulnya efek toksisitas timbal terhadap pembentukan hemoglobin. Meskipun demikian, beberapa penelitian sebelumnya melaporkan penurunan konsentrasi hemoglobin dapat terjadi pada kadar timbal dalam darah $>10 \mu \mathrm{g} / \mathrm{dL} .{ }^{1,15,17}$

Nilai rata-rata kadar timbal dalam darah yang rendah dapat disebabkan sumber pencemar paparan timbal terhadap anak di lokasi penelitian yang mungkin ternyata rendah, meskipun subjek penelitian memiliki risiko tinggi terhadap paparan timbal. Risiko tinggi terpapar timbal karena tempat tinggal berlokasi di kawasan yang tinggi polusi asap kendaraan bermotor (baik dari perempatan lampu merah yang padat kendaraan bermotor maupun area pemukiman yang sangat dekat dengan jalan-jalan kecil yang dilalui oleh kendaraan bermotor), sumber air dari ledeng yang berasal dari PAM (49,2\%), mainan atau cat rumah yang terbuat dari campuran timbal, dan sebagai perokok pasif. Penggunaan sumber air dari ledeng dapat menjadi salah satu faktor risiko tingginya kadar timbal dalam darah. Hal tersebut didukung oleh penelitian Albalak dkk ${ }^{21}$ di Jakarta. Albalak dkk melaporkan bahwa $40 \%$ anak pengonsumsi air sumur rumahan mempunyai risiko lebih rendah mempunyai 
kadar timbal dalam darah $>10 \mu \mathrm{g} / \mathrm{dL}$ dibandingkan yang mengonsumsi sumber air dari ledeng. Sakkir $\mathrm{dkk}^{22}$ juga melaporkan bahwa anak yang dalam keseharian keluarganya menggunakan sumber air dari ledeng mempunyai rata-rata kadar timbal dalam darah yang tinggi, yaitu $28,02 \mu \mathrm{g} / \mathrm{dL}$. Sumber paparan timbal terkait sumber air ledeng ini dapat berasal dari reservoir air utama atau dari pipa yang mungkin terbuat dari bahan yang mengandung timbal.

Perbedaan cara pengambilan sampel darah juga dapat memengaruhi timbulnya perbedaan hasil dengan penelitian lain. Pengukuran kadar timbal dalam darah melalui darah kapiler dapat menimbulkan hasil positif palsu (hasil lebih tinggi) karena kontaminasi kulit ataupun bahan dari tabung hematokrit yang digunakan. Dengan demikian, penggunaan darah kapiler tidak dapat digunakan sebagai alat diagnostik pengukuran kadar timbal dalam darah, tetapi hanya dapat digunakan sebagai skrining. Kadar timbal dalam darah yang tinggi melalui sampel darah kapiler harus dikonfirmasi dengan sampel darah vena. ${ }^{25}$

Penelitian kami memberikan gambaran kadar timbal dalam darah pada anak usia 1-6 tahun di Yogyakarta yang belum pernah dilakukan sebelumnya.Seharusnya, sesuai rekomendasi $\mathrm{CDC}$ dan $\mathrm{AAP}$, anak usia $<6$ tahun yang berisiko tinggi terpapar timbal sebaiknya dilakukan skrining kadar timbal dalam darah secara rutin. Meskipun demikian, penelitian kami memiliki keterbatasan, yaitu kadar timbal pada sumber paparan yang sebaiknya diperiksa juga (misalnya air, tanah, dan udara).

Disimpulkan pada penelitian kami bahwa tidak didapatkan korelasi antara kadar timbal dalam darah dengan kadar hemoglobin pada anak usia 1-6 tahun.

\section{Daftar pustaka}

1. Hegazy AA, Zaher MM, Abd MA, Morsy AA, Saleh RA. Relation between anemia and blood levels of lead, copper, zinc and iron among children. BMC Res Notes 2010;3:133.

2. Ahamed M. Environmental lead exposure as a risk for childhood aplastic anemia. Bio Science Trends 2011;5:38-43.

3. Patrick L. Lead toxicity part II: The role of free radical damage and the use of antioxidants in the pathology and treatment of lead toxicity lead/antioxidants. Altern Med Rev 2006;11:114-27.
4. Departemen Perhubungan. Statistik perhubungan 2008. Jakarta: Departemen Perhubungan;2008.

5. Sarwindaningrum I. Udara wirobrajan dan kantor pos Yogya tercemar. Diakses 7 Juli 2012. Didapat dari: http://oase.kompas.com/read/2009/12/11/21474797/udara. wirobrajan.dan.kantor.pos.yogya.tercemar

6. Desta. Transportasi: Jumlah kendaraan bermotor di Yogyakarta bombatis. Diakses 5 Juli 2012. Didapat dari: http://www.jagoannews.com/blog/2012/06/26/transportasijumlah-kendaraan-bermotor-di-yogyakarta-bombastisl

7. Goyer RA. Lead toxicity: Current concerns. Environ Health 1993;100:177-87.

8. Wisconsin Council on Families and Children. Sources and toxicology of lead exposure, 2000. Diakses pada 14 Januari 2016. Didapat dari:https://www.dhs.wisconsin.gov/ sites/default/files/legacy/R_Counties/HealthOfficerMaterials/ PolicyProcedures/WCLPPPHandbook.pdf.

9. Bradman A, Eskenazi B, Sutton P, Athanasoulis M, Goldman LR. Iron deficiency associated with higher blood lead in children living in contaminated environments. Environ Health 2001;1091:1079-85.

10. Turgut S, Polat A, Inan M, Turgut G, Emmungil G, Bican M, dkk. Interaction between anemia and blood levels of iron, zinc, copper, cadmium and lead in children. Indian J Pediatr 2007;74:827-30.

11. Florida Departement of Health. Childhood lead poisoning, screening \& case management guide. Florida: Florida Departement of Health;2008.

12. World Health Organization (WHO). Childhood lead poisoning. Geneva;2010.

13. Shah F, Kazi TG, Afridi HI, Baig JA, Khan S, Kolachi NF, dkk. Environmental exposure of lead and iron deficit anemia in children age ranged 1-5 years: a cross sectional study. Sci Total Environ 2010;408:5325-30.

14. Faizah L. Hubungan pemaparan partikel timah hitam $(\mathrm{Pb})$ udara dengan $\mathrm{Pb}$ darah dan kadar hemoglobin $(\mathrm{Hb})$ pada pekerja industri peleburan timah hitam (tesis). Semarang: Fakultas Kedokteran Universitas Diponegoro, 2002.

15. Jain NB, Laden F, Guller U, Shankar A, Kazani $S$, Garshick E. Relation between blood lead levels and childhood anemia in India. Am J Epidemiol 2005;161:968-73.

16. Liu J, McCauley L, Yan C, Shen X, Pinto-Martin JA. Low blood lead levels and hemoglobin concentrations in preschool children in China. Toxicol \& Environ Chem 2011:1-4.

17. Ahmad T, Mumtaz A, Ahmad D, Rashid N. Lead exposure in children living around the automobile and 
battery repair workshops. Biomedica 2009;25:128-32.

18. Froom P, Kristal-Bonch E, Benbassat J. Lead exposure in battery-factors workers is not associated with anemia. J Occup Environ Med 1999;41:120-3.

19. Keramati M, Sadeghian MH, Mood M. Correlation between iron deficiency and lead intoxication in the workers of a car battery plan. UHOD 2010;20:169-74.

20. Darmadji I. Hubungan antara kadar timah hitam dalam darah dengan kadar hemoglobin (Studi pada petugas parkir bawah tanah di Plaza Simpang Lima Semarang) [tesis S2]. Semarang: Universitas Diponegoro, 2003.

21. Albalak R, Noonan G, Buchanan S, Flanders WD, Gotway-Crawford C, Kim D, dkk. Blood lead levels and risk factors for lead poisoning among children in Jakarta,
Indonesia. Sci Total Environ 2003;301:75-85.

22. Sakkir B, Khidri MA, Sjafruddin A. Kadar timbal dalam darah pada anak-anak di kota Makassar. J Kesehatan Masyarakat Madani 2008;1:96-106.

23. Centre for Disease Control and Prevention. Low level lead exposure harms children: A renewed call for primary prevention. Atlanta: U.S. Departement of Health and Human Service. Pub Health Service; 2012.

24. Landrigan PJ \& Kellner CH. CDC updates guidelines for children's lead exposure. Environ Health Perspect 2012;120:A268.

25. Minnesota Departement of Health. Blood lead testing methods, report to the legislature. St. Paul, Minnesota Departement of Health; 2008. 